\title{
MODERNIZATION AS A SOCIAL PHENOMENON
}

\author{
${ }^{1}$ A. Sagikyzy, ${ }^{2}$ N. Abdykaimova, ${ }^{3}$ D. Zhanabayeva
}

\begin{abstract}
The article is devoted to the disclosure of the content and meaning of the phenomenon of modernization both in general and in relation to the task of modernization of Kazakhstan's public consciousness facing the Republic of Kazakhstan. It is shown that the concept of modernization originally arose in the course of Western scientists' understanding of the process and consequences of the transition of Western Europe from the feudal system to the capitalist one. Since the end of the XIX century and especially in the XX century, modernization began to be understood as the transfer of European standards of living and institutions to states and societies with a traditional way of life. It is noted that in connection with the task of modernization of Kazakhstan's public consciousness, the phenomenon of modernization should be interpreted somewhat differently. Modernization of public consciousness should not subject it to a complete modernization. It should synthesize the positive that has been accumulated for centuries with the positive that has been formed today, after Kazakhstan gained state independence
\end{abstract}

Keywords: Modernization, Modernity, Traditional Society, Capitalism, Islamic World, Kazakhstan, Public Consciousness.
1,2,3 Institute for Philosophy, Political Sciences and Religious Studies CS MES RK, Almaty, Kazakhstan

Corresponding Author:

D. Zhanabayeva,

dinara.jan@bk.ru

Reference to this article:

A. Sagikyzy, N. Abdykaimova, D. Zhanabayeva. Modernization as a Social Phenomenon // Adam alemi. - 2021. - № 4 (90). - P. 21-30.

This article was prepared as part of the funding of the Committee of Science of the Ministry of Education and Science of the Republic of Kazakhstan (Grant No. BR10965263 "Social modernization of Kazakhstan society: ideological and ideological foundations, conceptual models, socio-cultural processes, socio-political technologies").

\section{Модернизация әлеуметтік феномен ретінде}

\begin{abstract}
Аннотация. Мақала Қазақстан Республикасы алдында тұрған қазақстандық қоғамдық сананы жаңғыртуға қатысты модернизация феноменінің мазмұны мен мағынасын ашуға арналған. Модернизация ұғымы бастапқыда Батыс ғалымдарының Батыс Еуропаның феодалдық жүйеден капиталистік жүйеге көшу процесі мен салдарын түсінуі кезінде пайда болғандығы көрсетілген. XIX ғасырдың аяғынан бастап, әсіресе XX ғасырда еуропалық өмір сүру стандарттары мен институттарын дәстүрлі өмір салтымен мемлекеттер мен қоғамдарға көшіру модернизация деп түсініле бастады. Қазақстандық қоғамдық сананы жаңғырту міндетіне байланысты жаңғырту феномені басқаша түсіндірілуі тиіс екендігі көрсетілген. Қоғамдық сананы жаңғырту оны толығымен жаңаруға ұшыратпауы керек. Ол ғасырлар бойы қалыптасқан позитивтілікті, Қазақстан мемлекеттік тәуелсіздік алғаннан кейін қалыптасқан позитивтілікпен синтездеуі тиіс.
\end{abstract}

Түйін сөздер: модернизация, заманауилық, дәстүрлі қоғам, капитализм, ислам әлемі, Қазақстан, қоғамдық сана. 


\title{
Модернизация как социальный феномен
}

\begin{abstract}
Аннотация. Статья посвящена раскрытию содержания и смысла феномена модернизации как вообще, та и применительно стоящей перед Республикой Казахстан задачей модернизации казахстанского общественного сознания. Показано, что первоначально понятие модернизации возникло в ходе осмысления западными учёными процесса и последствий перехода Западной Европы от феодального строя к капиталистическому. Начиная с конца XIX и особенно в XX в. под модернизацией стали понимать перенос европейских стандартов жизни и институтов в государства и общества с традиционным укладом. Отмечается, что в связи с задачей модернизации казахстанского общественного сознания феномен модернизации должен трактоваться несколько иначе. Модернизация общественного сознания не должна его подвергать всецелому осовремениванию. Она должна синтезировать то позитивное, что было наработано столетиями, с тем позитивным, что сформировалось сегодня, после обретения Казахстаном государственной независимости.
\end{abstract}

Ключевые слова: модернизация, современность, традиционное общество, капитализм, исламский мир, Казахстан, общественное сознание.

\section{Introduction}

In the early 1990s, the topic and problem of modernization somewhat receded into the background, and the topic and problem of globalization came to the fore. However, the world began to change very quickly, it ceased to be unambiguously unipolar, the leader of globalization began to lose its position. The world is gradually becoming multipolar, so the study of globalization has lost its relevance. The phenomenon of modernization is again attracting attention.

The concept of modernization can be interpreted both broadly and more narrowly. Modernization, understood in a broad sense, is simply the transformation and development of anything in culture in accordance with urgent objective needs and interests. This kind of modernization is an integral companion of the evolution of human culture. Most often, the initiative of modernization comes from a single ethnic, ethno-national or national culture. Other cultures can be guided by this culture and bring themselves to the level of a culture that has carried out a modernization step. They take the latter as a kind of model (it is now "modern" for them) and adopt its achievements. They don't necessarily follow them literally. Strictly speaking, this is the only thing that can be called modernization. There is a concept of "catching up modernization". In this case, just modernization and catch-up modernization are only two aspects of a single natural-historical process.

The first meaning of the concept of modernization as applicable to the evolution of Western Europe from the Middle Ages to Modern Times has lost its meaning and can only be applied in historical research. The second meaning of this concept (the imposition of Western models on so-called traditional societies) continues to be relevant. Finally, at the present time, an opportunity is being created for the formation of a new meaning of the concept of modernization. It is applicable to a number of post-Soviet states, including Kazakhstan.

In this study, the method of unity of historical and logical is applied.

\section{The Essence and Meaning of the Phenomenon of Modernization}

The concept of modernization, as it entered social philosophy and political science, is associated with the concepts that appeared in the XIX century, in which the process of formation of the capitalist system in Western Europe in Modern times was conceptualized. The former societies (archaic, ancient and feudal) began to be 
defined as traditional, and the emerging new one as modern. There were different concepts of such a transition and the differences between the old and the new. E. Durkheim, for example, took as a criterion for distinguishing these types of societies the type of social connection he called "solidarity". The traditional type of society, according to him, is characterized by "mechanical solidarity" (or "solidarity by similarities"), while the non-traditional type of society is characterized by "organic solidarity" (or "solidarity caused by the division of labor"). He gives them the following characteristics. "If we try to mentally establish an ideal type of society, the cohesion of which would result solely from similarities, then we must imagine it as an absolutely homogeneous mass, the parts of which do not differ from each other and, therefore, are not adjusted to each other - in a word, devoid of any definite purpose and organization" [1, 166-167]. Such an aggregate, Durkheim notes, can be called a horde. However, in its pure form, such units did not exist. In fact, the horde as a non-independent element is part of the plan, and the clan association forms, according to Durkheim, "segmental societies with a clan basis." A different type is represented by societies based on "organic" solidarity. "They," writes E. Durkheim, "are built not by repeating homogeneous and similar segments, but by means of a system of various organs, each of which has a special role and which themselves consist of differentiated parts. The social elements here are not of the same nature, and at the same time they are located differently" [1, p. 173].

F. Tennis considered the transition from the old type of society to the new as a transition from community to society. Every community is a system of relations that can be both aimed at its preservation, that is, positive, and at its destruction. The subject for Tennis is positive relationships. He writes: "A group formed by such a positive attitude, perceived as a being or thing whose actions are united in their internal and external orientation, is called a connection [Verbindung]. This relationship itself, and thus the connection, is understood either as real and organic life - this is the essence of the community [Gemeinschaft] - or as an ideal and mechanical formation - this is the concept of society [Gesellschaft]" [2, pp. 9-10]. However, as G. S. Batishchev showed, the distinction between community and society was carried out even in the "German Ideology" of K. Marx and F. Engels (18451846) (see: [3, p. 300]).

K. Marx interpreted the transition from a traditional society to a new one based on his periodizing typology of social ties and relationships. He wrote: "The relationship of personal dependence (at first completely primitive) is the first form of society in which people's productivity develops only to a small extent and in isolated locations. Personal independence based on material dependence is the second major form in which a system of universal social metabolism, universal relations, comprehensive needs and universal potencies is formed for the first time" [4, p. 100-101]. Marx also identifies a third form, but it has practically not yet come. Consequently, for Marx, the transition from one form to the second consisted in the transition from the domination of the relations of personal dependence on the scale of the social whole to the domination of the relations of material dependence.

Marx's concept seems to be more solid for the following reasons. Marx wrote about capitalism: "In the structure of society that we are currently studying, the relations of people in the social production process are purely atomistic" [5, p. 102103]. The reverse side of this atomization was the reification of relations: they became "not directly the social relations of the persons themselves in their work, but, on the contrary, the material relations of persons and the social relations of things" [5, p. 83]. The capitalist system is based on the processes of industrialization and urbanization. She asserted a new 
modernity, in relation to which not only the entire past, but also the present, which was based on the traditional way of life, turned out to be in the status of modernity. Individualism and egoism are established as the norm. A single individual appears to himself (at least in his consciousness) as a self-sufficient center, while everything around him (including other people) is just a periphery and a more or less suitable means, or something useless, or even harmful. The motivation of his actions is dominated by need motivation. For him, having means more than being. Competition, that is, the struggle for his private interests determines his behavior. This is the path of capitalist society as a modern society, which the West has been following since the XVII-XVIII centuries to this day. The definition of a modern capitalist society as a post-industrial, informational, knowledge society, etc-, is only a characteristic of certain changes in a single type of social structure. Therefore, modernization is not a one-time act, but an evolving process.

Let's note one more aspect. Traditional societies have come to be understood as societies dominated by the agrarian economy, and modern, modernized industrial societies. Thus, modernization began to be understood primarily as the industrialization of agrarian societies. In this sense, the industrialization carried out in the Soviet Union after the Bolsheviks came to power looks like modernization. However, the narrow economic understanding of modernization was subsequently overcome. Modernization now means the transformation of all spheres and levels of society and culture. M. A. Mozheyko writes: "Industrialization and modernization, thus, are two sides of the same process of the formation of an industrial society, comprehensively understood in all its aspects" [6, p. 436]. In our opinion, the cited author admits reductionism. But not in the sense that he incorrectly interprets the real processes of modernization; they really are now such that their basis is precisely industrialization, and the rest appears only as an "appendix" to it. M.A. Mozheyko admits reductionism in the worldview, i.e. in terms of depicting the essence of modernization as such.

In the twentieth century, another aspect was revealed in the concept of "modernization". The fact is that the West has begun to impose its standards, values, and institutions on some states with a traditional way of life. Therefore, modernization in these states began to be perceived as Westernization. To this J. Germani notices: "The modernization process was initially perceived as Westernization or Europeanization, as it began in Europe and spread to other countries. However, at the new stage, modernization can no longer be considered as only the transfer of European institutions to other parts of the world or as a transition to any one fixed type of society" [7, p. 464]. Germani notes that modernization covers the entire society as a whole, not just individual spheres; that there may be a number of modernization models; that different paths may lead to modernization.

Usually, Germani notes, they are afraid of unification and homogenization of original cultures. However, he believes, one should not be afraid of this. "In any case," he writes, "the result will be a new world civilization combining the heritage of both Western and non-Western cultures. The process of modernization" he adds "is a permanent revolution that does not have a predetermined ultimate goal" $[7, \mathrm{p}$. 464-465]. S. Huntington also argues that "modernization does not necessarily mean Westernization. Non-Western societies can modernize and have already done so without abandoning their native cultures and without adopting Western values, institutions and practical experience" $[8$, p. 112]. He is supported by P. L. Berger, who states that "not one road can lead to modernization, but several" [9, p. 20]. Usually in these cases, reference is made to the experience of a number of countries in 
the Far Eastern region and, first of all, Japan. Mozheiko writes: "The specificity of "eastern modernization" is that this variant of it is carried out on the basis not of destruction, but - on the contrary - of strengthening the tradition of communality characteristic of Eastern culture: Japan demonstrates a kind of "communal capitalism", replacing only the subject - addressee of patriarchal collectivism and paternalism, but without destroying the type of communal consciousness itself: dissolution in the traditional collective is replaced by being integrated into the collective of the enterprise, loyalty to the family - loyalty to the firm, a sense of paternalistic concern on the part of the community - a sense of social security, attention from the company to the adjustment of the personal fate of the employee ..." [6, p. 437].

As a result of this kind of modernization, the former foundation of Japanese society and its culture (i.e., the system of personal dependence relations) has been preserved in its form, but at the same time its content has changed. In this connection, it is recalled that K. Marx, in his sketches of the response to the letter of V. I. Zasulich (1881), recommended something similar for Russia, in which at that time the "agricultural community" was still preserved. "In all of Europe," Marx writes, "it alone is the organic, dominant form of life of a vast empire. Common ownership of land provides it with a natural basis for collective appropriation, and its historical environment - the existence of capitalist production simultaneously with it - provides it with ready-made material conditions for cooperative labor organized on a large scale. It can, therefore, take advantage of all the positive acquisitions made by the capitalist system without passing through its Kavdinsky gorges" [10, p. 419-420].

The points of view on the phenomenon of modernization, which are optimistic in their tone, were given above. But there are also opposing positions. S. H. Nasr, for example, tried to analyze what modernization is for the Islamic world. For the West, the process of modernization is a natural process prepared by all previous development. Therefore, its pace does not affect Western culture as much as Eastern culture, in particular Islamic culture. "One way or another," S. H. asserts. Nasr- The West loses less before the onslaught of modernism, while the considerable spiritual wealth accumulated by the East is constantly in danger of destruction by the West through books, radio or a bulldozer" [11, p. 481]. S. H. Nasr notes that a Muslim living somewhere in the outback, far from the center, lives a more or less quiet life, because modernization has not yet touched him. But a Muslim living in the center, especially in the capital, lives in constant tension. After all, he is influenced and in his inner world, two opposing types of worldview and two mutually exclusive clusters of values compete and even antagonize. So it is in all spheres of life, in all spheres of culture. S.H. Nasr at the same time seeks to expose the imaginary superiority of Western civilization, from which modernization proceeds. He's writing: "Modern civilization, which has developed in the West or has spread from there to the East, prides itself on the development of the critical ability of the mind and the power of objective criticism, while in fact it is, in fact, the least critical of all known civilizations and does not have the objective criteria necessary to examine and criticize its own activities. This is a civilization that is not capable of carrying out any reform, since it is not able to reform itself" [11, p. 483].

It is not difficult to notice that the cited author also admits bias and uncriticism towards himself and the culture he represents. Criticism of Western culture has been conducted for a long time and in the West itself. Another thing is that the powers that be do not listen to this much. Nevertheless, through the efforts of Western thinkers, Europo- and generally Western-centrism in relation to nonWestern cultures was exposed. 
But we cannot discount the fact that if ideological West-centrism has been largely overcome, then practical (political and economic) is still far from being overcome. Be that as it may, but modernization in its content is not free from Westernization. In the mid-50s of the twentieth century, M. Heidegger spoke about the process that he called "the final Europeanization of the earth and man" [12, p. 281]. Little has changed since then.

The most unacceptable for many Eastern cultures, especially for the cultures of the Islamic region, is the tendency towards secularization, which is present in the strategy and tactics of modernization, moreover, the trend is constantly increasing. In Islam, as you know, there is no division into sacred and secular spheres, it is still sacred. Therefore, it is in the Islamic world that modernization faces serious problems. This is also recognized by modernization theorists. Thus, the above-quoted J. Germani writes: "In recent decades, some negative aspects of the modernization process have generated various forms of resistance. Modernization leads to the emergence of many different ethical, aesthetic and ideological tendencies, which makes it difficult to form common values" [7, p. 466]. And without this, a full-fledged modernization of nonWestern societies is hardly possible.

At one time, the Russian thinker N.Y. Danilevsky wrote about the harmfulness of such enterprises. A. J. Toynbee agrees with him. According to him, "elements of culture that are quite harmless and even beneficial on native soil can turn out to be dangerous and destructive in someone else's social context. On the other hand, once alien elements establish themselves in a new environment, they tend to attract other elements of their own culture" [13, p. 578]. And thus complete the decomposition and destruction of the culture into which they have infiltrated. He, in particular, shows "what harm a certain institution can cause, torn out of the usual social sphere and forcibly transferred to another world" [14, p. 183].
For a long time, the equivalent of the concept of "modernization" was the concept of "Westernization", that is, the transfer and sometimes forcible imposition of standards, values, technologies, lifestyle and even some institutions formed in Western Europe into non-Western societies and cultures. Since the middle of the twentieth century, they also began to talk about the processes of Americanization. But in any case, modernization in this sense is bringing "non-modern" societies into line with advanced capitalist countries. This, therefore- is a radical transformation of traditionalist societies and cultures. Consequently, the so-understood modernization is a transition not to any random, but to a strictly defined modernity - to capitalist modernity.

\section{Modern Kazakhstan: the Problem of Modernization of Public Consciousness}

In 2017, the article of the First President of the Republic of Kazakhstan N.A. Nazarbayev "A look into the future: modernization of public consciousness" was published. In it, the head of state called, in particular, for openness of consciousness, noting that such openness means at least three features. Firstly, an understanding of what is happening in the world and around you. Secondly, the openness of consciousness is a willingness to change, which brings a new technological way. Thirdly, the ability to adopt someone else's experience, learn from others. Thus, the citizens of Kazakhstan were given the task of modernization (which can also be interpreted as a transformation) of Kazakhstan's public consciousness.

It is clear that in this case modernization should be understood differently. But to explain this understanding, we need to turn to the Kazakh reality - not only to the modern one, but also to the one that existed several decades ago. By the time the task of modernization (transformation) of Kazakhstan's public consciousness was set after the destruction of the Soviet Union, almost 30 years had passed. During this 
time, a new generation of Kazakhstanis has formed and another one is being formed, for which the Soviet reality is an almost mythical state. At the same time, many of those who were born in the 1930s and subsequent years are still alive, i.e. those for whom the Soviet reality is an era in which they were formed as individuals having absorbed the basic ideological and value orientations that have not succumbed to inflation for centuries and which the party ideology of the Soviet Union could not distort.

The main, basic moments of the Soviet worldview and Soviet values were, first of all, the harmony of society and the individual, the value of an open, tolerant attitude to any other person, regardless of his racial, national, ethnic, confessional and other private affiliation. The formula "Soviet people", of course, was heavily ideologically loaded, but in its essence it expressed the actual state of affairs. For a person, another person was significant primarily not by his national and similar characteristics, but mainly by ethical characteristics (whether he is decent or dishonest, sincere or false, etc.), intellectual (whether he has some higher interests or he is closed to his purely private interests and needs, whether he is drawn to knowledge or indifferent to them, etc.), political in a broad sense (he is a patriot, a nationalist or a "don't care"). And so on.

Whathappened as a result of the collapse of the USSR? First, a new system has been established, actually capitalist. Secondly, religion was rehabilitated. Thirdly, the principle of individualism and selfishness, as well as the cult of consumerism and the cult of money began to be imposed from the West. In addition, in the first two decades, the appeal of each titular ethnic group to the closed pages of its history at one time gave rise to manifestations of ethno- and/or nation-centrism in various Union republics that became independent states to varying degrees. In Kazakhstan, the latter did not last long, but it still gave its consequences. This manifested itself in an uncritical apology and reception of both the positive that took place in the ancient culture of the Kazakhs, and what should be considered obsolete and not in line with the spirit of modernity. However, as noted, this is a specific modernity.

The sovereign states that grew up on the wreckage of the USSR instantly reoriented to a market economy and ideologically attached to them the concepts of "democratic structure of society" and "rule of law". "Market economy" is a euphemism for the concept of "capitalistically organized economy". In other words, some kind of socialism with its certain undoubted humanistic achievements was abruptly replaced by capitalism. Immediately there was a property and status stratification of society. Many professions turned out to be unclaimed in the new way, and people had to join the ranks of the unemployed. Many citizens have experienced various kinds of identity crises.

In the post-Soviet sovereign states came that form of capitalism, which was called consumer society. In this society, a powerful factor is the cult of money, obtained at any cost, neglecting the most elementary ethical maxims. Society has sharply stratified into the superrich, the middle-income, the low-income and people (and they initially turned out to be the majority) living below the poverty line. And if in the Soviet Union the basic, components of consciousness were, in principle, common to all ( for the minister and for the janitor), in principle they were uniform, then in modern postSoviet societies there is no single social consciousness in its composition and in its tonality. This consciousness is divided into several (at least four) - if not class in the classical sense of the word, then contingent - levels, or layers, of social consciousness.

Strictly speaking, modern post-Soviet society, including, of course, Kazakhstan, largely in terms of its moral climate rests on the consciousness of gradually and steadily thinning carriers of the former - Soviet and pre-Soviet - matrix of public consciousness. 
The generation born after the destruction of the Soviet Union and emerging now, the contingent that, according to the age criterion, belongs to the youth, and the already formed adolescence over the years of state sovereignty under the direct and indirect influence of modern Western civilization is a carrier of consciousness, directly opposite in its tonality to the traditional consciousness of the peoples of Kazakhstan. This consciousness is largely fueled by modern information and communication technologies, not to mention its purposeful manipulation through various channels, including through advertising, which has taken purely capitalist forms.

The current state of Kazakhstan is characterized by the rapid development of computer technologies, attempts to create artificial intelligence, successes in the field of nano-technologies, biotechnologies, etc., that is, what is called convergent technologies (NBICS). All this also has a significant impact on the formation of individual and public consciousness of Kazakhstanis. The era has changed. In this situation, it would be unwise to let the development of consciousness take its course. The task of modernization of Kazakhstan's public consciousness is focused on this.

It becomes clear that the meaning of the modernization of consciousness, on the one hand, is the need to bring it into line with the phenomena and requirements of modernity, but on the other hand in accordance with not all phenomena and trends of the current modernity. Modernization of consciousness, by the highest account, should mean something more than just adaptation to modern reality, primarily to its Western models. Modern Western civilization is characterized by a kind of theatricality: it is dominated by all kinds of shows, festivals, flash mobs, etc., where everything is put on display and for the amusement of the crowd. Consequently, the consciousness of the masses has a very superficial character.
The task of modernization of Kazakhstan's public consciousness is one of the conditions for solving a more fundamental task focused on the entry of the Republic of Kazakhstan into the top thirty leading countries of the world. And indeed, in order to solve this last task, the citizens of the Republic of Kazakhstan must have somewhat different characteristics than those that the majority has today. The task of modernizing the public consciousness of the Kazakh society cannot and should not be interpreted in the sense that those components of it that for many centuries have ensured the unity of peoples, the basic ethical value bonds, should be completely removed from the public consciousness of Kazakhstan. Therefore, the task consists, first of all, in the need to form some unity, ideally - in apocatastasis (gathering together) those components of social consciousness that were present in the traditional forms of consciousness of the peoples inhabiting Kazakhstan, including the positive as part of the consciousness of Soviet society. Essential among the peoples inhabiting the Steppe, whatever they were called, was the type of relationship between people on which Kazakh society was built from the moment of its inception. This is an organic type of relationship. They are characterized by openness to each other, collectivism, mutual assistance. The same relations were fixed in the public and individual consciousness of the Kazakhs, crystallized in the form of fundamental values. The same was contained in the minds of other ethnic groups inhabiting Kazakhstan.

The task of modernization (in the designated sense) of Kazakhstan's public consciousness is not simple and for its solution requires a special approach to it, which includes the development of an adequate model of this modernization. First of all, it must be borne in mind that we mean the public consciousness in its entirety, the consciousness of the entire Kazakh society without dividing into believers and non-believers, rich and poor, 
etc. This model can be a set of measures aimed specifically at the transformation of Kazakhstan's public consciousness in the direction of each citizen's awareness of the tasks assigned to him by the state and willingness to participate in their solution. But in order to develop this model, it is necessary to have before your mind's eye a picture of modern Kazakh consciousness and not only a finished picture, but also how it was formed.

Modern Kazakhstan is a multiethnic state. Along with the worldview of the people, an even deeper level of consciousness has been formed for centuries - mentality (mentality is an attribute of an individual). The traditional mentality of the Kazakh people is characterized by a symbiosis of a) the secular layer induced by practical life activity, b) the primordial religious layer and c) the Sunni Islam of the Hanafi Madhhab introduced around the tenth century. The presence or absence of anthropo- and socio-morphism in the public consciousness and worldview makes its own adjustments. 73 years of Soviet power, under the influence of state ideology and under the influence of the education system, changed public consciousness and worldview, which also influenced the mentality. Religious content was eliminated from them and replaced entirely by secular consciousness. Mostly only the most ancient beliefs and prejudices have survived from the past. The analysis showed that the traditional Kazakh mentality as a whole is developing in the direction of a unified Kazakh mentality through synthesis with the mentalities of other peoples inhabiting Kazakhstan. Of course, during the years of Soviet power, under the influence of state ideology and under the influence of the education system, the traditional public consciousness and worldview changed, which also influenced the mentality. Religious content was eliminated from them and replaced entirely by secular consciousness.
In this regard, it became clear that it is important not just to "modernize" consciousness, but to make it deeper, wider, higher, i.e. to bring it in line with the requirements that the Republic of Kazakhstan faces today. Therefore, it becomes quite obvious the need for education and upbringing in the broadest and deepest sense (including the education of spiritual and sensual principles in a person, the formation of a worldview and a culture of thinking, including through philosophy). The modern task of modernizing consciousness is to teach people to interact harmoniously not only with things, but primarily with people. The problem of contact, dialogue and mutual understanding is the main practical problem and task of today and tomorrow.

\section{References}

1 Durkheim E. On the division of social labor // He is. On the division of social labor. The method of sociology. - M.: Nauka, 1991. - P. 3 $-390$.

2 Tennis F. Community and society. Basic concepts of pure sociology. - St. Petersburg: Vladimir Dal, 2002. - 451 p.

3 Batishchev G. S. Introduction to the dialectic of creativity. - St. Petersburg: ZHGI, 1997. - 463 p.

4 Marx K. Criticism of Political Economy (draft sketch of 1857-1858) [First half of the manuscript] // Marx K., Engels F. Essays. - Ed. 2-E. - T. 46. Part I. - M: Politizdat, 1968. - P. 49559.

5 Marx K. Capital. Criticism of Political Economy. Vol. 1. Book I: the process of capital production //Marx K., Engels F. Essays. - Ed. 2-E. - T. 23. - M: Politizdat, 1960. - 907 p.

6 Mozheyko M. A. Modernization concept // The newest philosophical dictionary. - Minsk: Publishing House V. M. Skakun, 1998. - P. 435 $-438$.

7 Germani J. The main characteristics of the modernization process // Comparative study of civilizations. - Textbook. - M.: Aspect Press, 2001. - P. 464 - 467.

8 Huntington S. Clash of civilizations. - M.: AST, 2003. - 505 p.

9 Berger P. L. Introduction. Cultural dynamics of globalization //Multi-faceted globalization. 
Cultural diversity in the modern world. - M.: Aspect Press, 2004. - P. 8-24.

10 Marx K. Sketches of the answer to the letter of V. I. Zasulich // Marx K., Engels F. Essays. Ed. 2-E. - T. 19. - M.: Politizdat, 1961. - P. 400 421.

$11 \mathrm{Nasr}$ S. H. On the clash of the principles of Western and Islamic civilizations // Comparative study of civilizations. - Textbook. - M.: Aspect Press, 2001. - P. 481 - 483.

12 Heidegger $M$. From the dialogue about the language between the Japanese and the questioner // The same. Time and being. Articles and speeches. - M.: Republic, 1993. - P. $273-302$.

13 Toynbee A. J. Comprehension of history. Collection. - M.: Progress, 1991. - 731 p.

14 Toynbee A. J. Civilization before the court of History // Civilization before the court of history. Collection. - M.: Publishing House of the Group "Progress"; "Culture"; - St. Petersburg: "Juventa", 1995. - P. 19 - 154.

\section{INFORMATION ABOUT AUTHORS}

Ayazhan Sagikyzy

Nazken Abdykaimova

Dinara Zhanabayeva

Аяжан Сағиқызы

Назкен Тлеубековна Абдыкимова

Динара Мұхтарқызы Жаңабаева

Аяжан Сағиқызы

Назкен Тлеубековна Абдыкимвона

Динара Мұхтарқызы Жаңабаева
Professor, Doctor of Philosophical Sciences, Chief Researcher, Al-Farabi Kazakh National University, Institute for Philosophy, Political Science and Religious Studies of the CS MES RK, Almaty, Kazakhstan

Researcher, Institute for Philosophy, Political Science and Religious Studies of the CS MES RK, Almaty, Kazakhstan

PhD, Leading Researcher, Institute for Philosophy, Political Science and Religious Studies of the CS MES RK, Almaty, Kazakhstan

философия ғылымдарының докторы, профессор, бас ғылыми қызметкер, Әл-Фараби атындағы Қазақ ұлттық университеті, ҚР БҒМ ҒК Философия, саясаттану және дінтану институты, Алматы, Қазақстан

ғылыми қызметкер, ҚР БҒМ ҒК Философия, саясаттану және дінтану институты, Алматы, Қазақстан

PhD, аға ғылыми қызметкер, ҚР БҒМ ҒК Философия, саясаттану және дінтану институты, Алматы, Қазақстан

доктор философских наук, профессор, главный научный сотрудник, Казахский национальный университет имени Аль-Фараби, Институт философии, политологии и религиоведения КН МОН РК, Алматы, Казахстан

научный сотрудник, Институт философии, политологии и религиоведения КН МОН РК, Алматы, Казахстан

$\mathrm{PhD}$, ведущий научный сотрудник, Институт философии, политологии и религиоведения $\mathrm{KH} \mathrm{MOH}$ РК, Алматы, Казахстан 